Helgoländer wiss. Meeresunters. 30, 283-294 (1977)

\title{
A preliminary carbon budget for a part of the Ems estuary: The Dollard
}

\author{
F. B. VAN Es \\ Biologisch Onderzoek Eems-Dollard Estuarium; Texel, The Netherlands
}

\begin{abstract}
During 1975, measurements were made to quantify all sources of input of organic matter in the Dollard. This made a comparison possible between in situ primary production, import from natural sources and organic waste discharges in terms of organic carbon. In order to make a carbon budget, mineralization and the amount of organic matter buried in the sediment was also measured. Input of organic carbon was mainly based on primary production on the tidal flats (measured in situ as $\mathrm{O}_{2}$ production, $9.3 \times 10^{6} \mathrm{~kg} \mathrm{C} \cdot$ year ${ }^{-1}$ ), accumulation of suspended matter originating from the North Sea and the River Ems (maximal $37.1 \times$ $10^{6} \mathrm{~kg} \mathrm{C} \cdot$ year $\left.^{-1}\right)$ and discharge of heavily polluted water $\left(33.0 \times 10^{6} \mathrm{~kg} \mathrm{C}^{-y^{2}}{ }^{-1}\right)$. Input from primary production in the water phase was negligibly low $\left(0.7 \times 10^{6} \mathrm{~kg} \mathrm{C} \cdot\right.$ year $\left.^{-1}\right)$. Loss of organic carbon was due to mineralization in the sediment (measured in situ as oxvgen consumption, $18.2 \times 10^{6} \mathrm{~kg} \mathrm{C} \cdot$ year $^{-1}$ ), mineralization in the water phase (using the BOD technique, $7.2 \times 10^{6} \mathrm{~kg} \mathrm{C} \cdot$ year $\left.^{-1}\right)$ and burying of organic matter in the sediment $\left(9.9 \times 10^{6} \mathrm{~kg}\right.$ $\mathrm{C} \cdot$ year $^{-1}$ ). The loss of dissolved organic matter to the adjacent Waddensea was not measured but must be considerable. Allochthonous detritus was the main source of energy for the foodwebs in the Dollard. The role of bacteria as an important source of food for higher organisms in the Dollard is discussed.
\end{abstract}

\section{INTRODUCTION}

Estuaries are often areas where allochthonous material of natural origin is deposited, due to hydrological factors. This material consists partly of particulate organic detritus, an extra source of energy that makes intensive biological activity in such estuaries possible. This activity requires large amounts of oxygen. Although in shallow estuaries the tidal movement establishes a good oxygen supply by reaeration, undersaturation may occur as a result of the aerobic mineralization (de Groot \& Postma, 1968).

The populations of various organisms in estuaries are believed to be adapted to such enriched environments. Caspers (1968) assumed that introduction of organic waste water was essentially only an extension of natural pollution.

The Ems estuary receives organic matter both from natural sources and from waste water discharges. In the "Biologisch Onderzoek Eems-Dollard Estuarium" most of the trophic levels in the estuary are at present studied by a group of biologists. The aim of this investigation is to describe the biological state of the estuary and to 
predict the effects of organic pollution. This paper describes an attempt to quantify both sources of imported organic matter and the in situ primary production in the Dollard, a part of the Ems estuary, making a comparison on basis of organic carbon between in situ production and import possible. The amount of the available organic carbon that is oxidized in the system by mineralization was also measured. And thus a carbon budget could be made.

\section{The Ems Estuary}

The Ems estuary is a part of the Dutch-German Wadden Sea (Fig. 1). Its estuarine characteristics are established by the influx of fresh water from the River Ems which is mixed with sea water, mainly by tidal movement. This mixing causes a gradient in salinity and suspended matter in the waterphase (Kühl \& Mann, 1954, 1973; Dorrestein, 1960). The mechanism of inward transport of suspended matter was described by Postma $(1954,1961)$. Van Straaten (1960) showed that material finally deposited in the Dollard is mainly of marine origin.

The Dollard consists of extended tidal flats $\left(79 \mathrm{~km}^{2}\right)$ covering $80 \%$ of its area. The main tidal channels contain $30 \times 10^{6} \mathrm{~m}^{3}$ and $157 \times 10^{6} \mathrm{~m}^{3}$ water respectively, at low and high tide (Reenders \& van der Meulen, 1972). This means that most of the water enters and leaves the system two times per day. A slight stratification in salinity can be observed at low tide. The average tidal range is $3.20 \mathrm{~m}$ (Ministerie van V \& W, 1974). The river water is separated from the watermass in the Dollard by the GeiseLeitdamm, so exchange can only occur further outward and during storm high tides.

Organic wastewater from potato flour mills is introduced into the estuary in the south-east by the Westerwoldse A, a small river, from which water is sluiced out during low tides. This causes heavy pollution in parts of the Dollard.

\section{MATERIALS AND METHODS}

Surface water samples were taken in the main tidal channel by the research vessel "Ephyra" at low tide (cruises) or over the tidal flats by fast rubber boats at high tide (surveys). Duplicate samples for the determination of suspended matter were collected on Whatman GF/C filters. For the determination of organic carbon in the suspended matter samples, the same filters were replaced in a filterholder, incubated with $\mathrm{HCl}$ $(1,2 \mathrm{~N})$ for $3 \mathrm{~min}$ to remove carbonates, and washed with distilled water. Organic carbon collected on the filters was determined with a Coleman model 33 CarbonHydrogen analyser. Mineralization in the water was measured in $600 \mathrm{ml}$ flasks as a $24 \mathrm{~h}$ oxygen demand $\left(\mathrm{BOD}_{1}\right.$ ) with an electrode (Yellow Springs Instruments model 5739). The electrode was calibrated in air saturated bidistilled water in flasks of the same size. The flasks were provided with a teflon coated stirring bar and an adaptor to hold either a plexiglass stopper or the electrode. For the oxygen measurements the flasks were placed on a magnetic stirrer. The accuracy of the $\mathrm{BOD}_{1}$ measurement proved to be better than $0.03 \mathrm{mg} \mathrm{O}_{2} \cdot 1^{-1}$. day ${ }^{-1}$. 


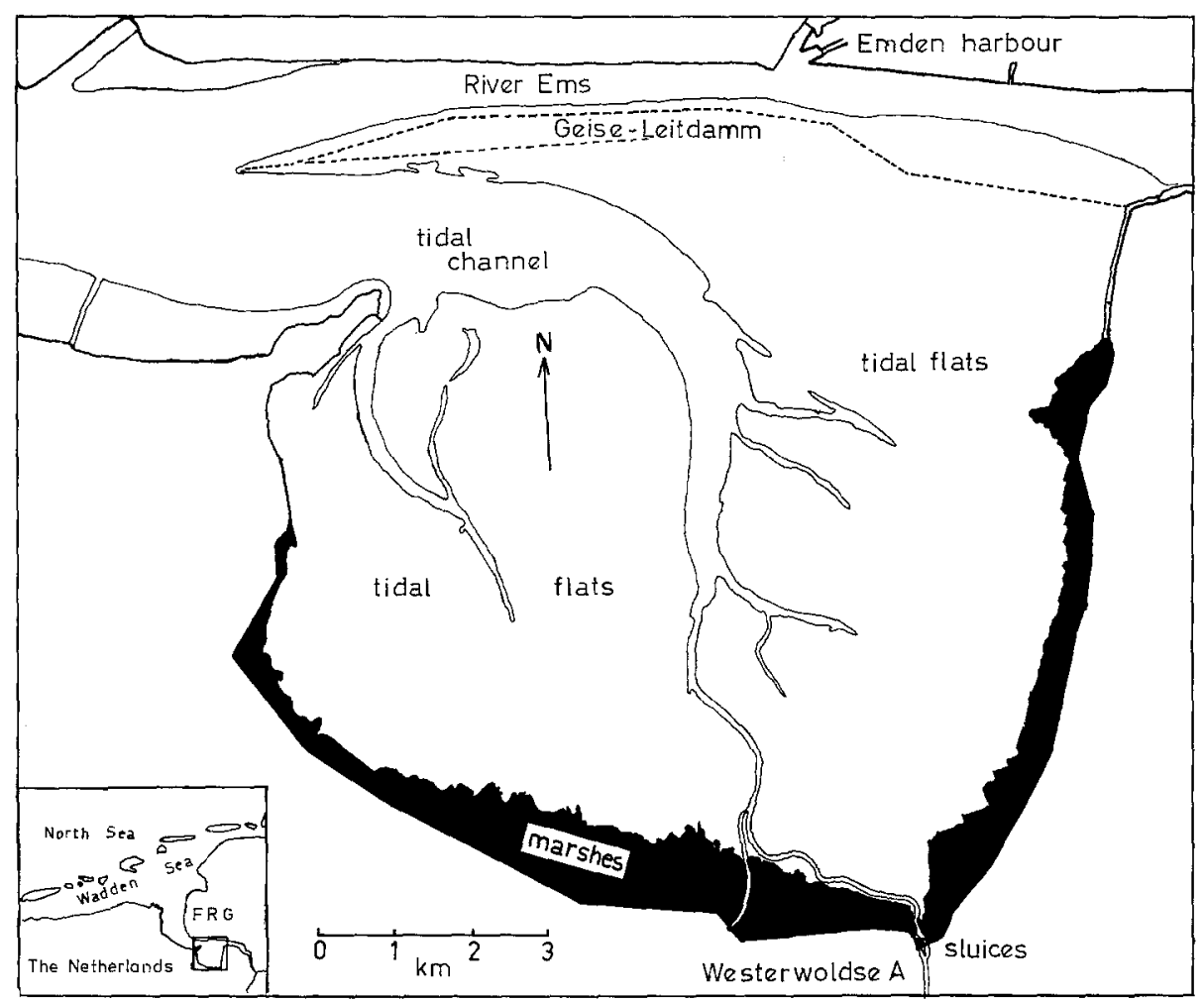

Fig. 1. Map of the Dollard (part of the estuary of the River Ems)

The concentration of organic matter in the waste water discharged from the Westerwoldse $A$, has been measured since 1971 by the "Rijksinstituut voor de Zuivering van Afvalwater", Sappemeer, as the chemical oxygen demand (COD) (RIZA, unpublished results). Paralell determinations of the organic carbon content in 105 samples analysed with a Beckman Carbon Analyser gave a high linear correlation $(r=0.987)$. This made conversion of COD values to organic carbon concentrations possible by using the equation organic $\mathrm{C}=0.324 \times \mathrm{COD}$.

The gross primary production on the surface of the tidal flats as well as the mineralization in the sediment were measured in situ by following the oxygen concentration in one light and two dark incubators of the bell jar-type. The procedure described by Pomeroy (1959) was followed with some modifications. Plexiglass cylinders (diameter $30 \mathrm{~cm}$ ) with a plain plexiglass lid were used instead of glass bottles. This gave a more natural light regime in the incubators (Vollenweider, 1969). A constantly operating magnetic stirring bar kept the water (volume 3.0 1) well mixed, without disturbing the sediment surface in the incubator. After an equilibration period of $15 \mathrm{~min}$, the first duplicate $100 \mathrm{ml}$ samples were withdrawn for Winkler determinations of dissolved oxygen. Good duplicate values were obtained when at least one volume of water was sucked through the Winkler flasks. During sampling, the 
incubator was pushed further into the sediment to compensate for the decrease in the water volume. Subsequent samples were taken at intervals of $1 / 2-11 / 2 \mathrm{~h}$ and $1-3 \mathrm{~h}$, depending on the expected activity. The incubators were filled with water collected in the neighbourhood of the sampling station. Oxygen production and consumption in this water was measured in separate bottles. Changes in oxygen concentrations in these bottles within a $3 \mathrm{~h}$ period were always low. Thus no corrections had to be applied, and changes in oxygen concentrations in the incubators could be attributed to benthic activity only. In the calculation of this activity, corrections were made for the decrease in water volume, due to sampling.

Oxygen production and consumption measurements were always made during low tide, a possible tidal rhythm was not taken into account. The gross production was calculated from the sum of increase of oxygen concentration in the light incubator and the average decrease in the dark incubators. This production was extrapolated to the whole photic period of the station for that day. The photic period was defined as the time of the day between sunrise and sunset that the station was not covered with a water layer of more than a few centimeters. In most cases the floodwater was so turbid that a water column of $10 \mathrm{~cm}$ would already prevent most of the sunlight to penetrate to the sediment. Thus the primary production rate probably had a rapid decline after the station was flooded.

The organic carbon content in the sediment was determined by wet oxidation, following the method of Kurmies with some modifications (Mebius et al., 1957). A known amount of $\pm 1 \mathrm{~g}$ well ground oven dried sediment, $20 \mathrm{ml}$ sulphuric acid and $10 \mathrm{ml}$ of a $2 \mathrm{~N}$ potassium dichromate solution was incubated in a bath of boiling water for $1 \frac{1}{2}$ hours. After cooling the volume was adjusted to $100 \mathrm{ml}$. The excess bichromate was titrated with thiosulphate using a Radiometer Titrator TTT 2 for a potentiometric end point determination and a Radiometer autoburette $\mathrm{ABU} 13$.

\section{RESULTS}

\section{Importoforganic matterfrom the outer part of the estuary and the River Ems}

P. de Wolf (unpublished) calculated the total import of suspended organic matter in the Dollard from the raise of the sediment surface in the Dollard $( \pm 0.8 \mathrm{~cm}$. year $^{-1}$ ) and the decrease in the water volume over a number of years as measured by the "Studiedienst Delfzijl van Rijkswaterstaat" (Reenders \& van der Meulen, 1972). The decrease was $11 \times 10^{6} \mathrm{~m}^{3}$ in 18 years, the average thus was $0.61 \times 10^{6} \mathrm{~m}^{3}$. year $^{-1}$. A net import of the same volume of deposited material must have caused this decrease. The tidal flat sediment in the Dollard has an average specific gravity of $1.6 \mathrm{~g} \cdot \mathrm{cm}^{-3}$ and a water content of $30 \%$. Thus the import of suspended matter on dry weight base was $0.7 \times 10^{9} \mathrm{~kg} \cdot$ year $^{-1}$. The average organic carbon content of the suspended matter in the waterphase was calculated from the data in Table 1. For the calculations the water body was divided into 2 sections. The heavy polluted inner part in the south-east stays in the Dollard during the whole tidal cycle. This part 
A preliminary carbon budget

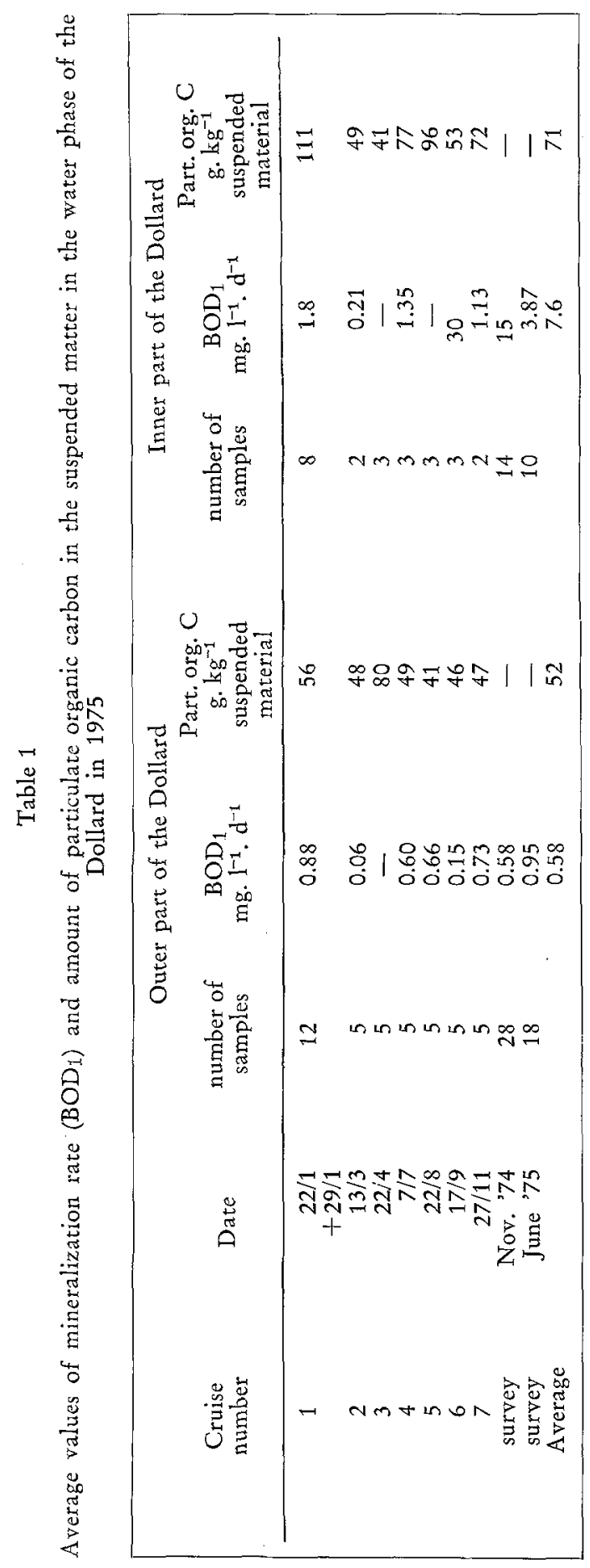


accounts for $1.35 \times 10^{6} \mathrm{~m}^{3}$. A large part of the rest of the water volume does not stay in the Dollard during the whole tidal cycle. Its average volume is $(28.6+0.5 \times 127)$ $\times 10^{6}=92.1 \times 10^{6} \mathrm{~m}^{3}$. The average organic carbon content of the suspended matter was $(1.35 \times 71+92.1 \times 53): 93.45=53 \mathrm{~g}^{\mathrm{kg}}{ }^{-1}$ (dry weight). In the following calculation it is assumed that during sedimentation this organic fraction behaves like the inorganic, although this will give a maximum value. For living organisms this assumption is probably wrong, but they form less than $5 \%$ of the organic fraction on the basis of carbon (Manuels \& Postma, 1974). Thus in the Dollard maximal $0.053 \times$ $0.70 \times 10^{9} \mathrm{~kg}=37.1 \times 10^{6} \mathrm{~kg} \mathrm{C} \cdot$ year $^{-1}$ is deposited in average $\left(400 \mathrm{~g} \mathrm{C}^{-\mathrm{m}^{-2}}\right.$. year $^{-1}$ ).

The import of suspended matter from the River Ems could not be determined separately because its concentration in the oligohaline zone was not sufficiently known. The measured concentrations fluctuated too much for a valid calculation.

\section{Importoforganicmatterfrom wastedischarges}

The import of organic matter from waste discharges, through the Westerwoldse A was calculated from the water volume that is discharged by each tide, as measured by the "Rijkswaterstaat" (unpublished) and the organic carbon content of this water.

Table 2

Waste discharges from the Westerwoldse A, expressed as $\mathrm{kg} \mathrm{C}$ per period. Values were calculated from chemical oxygen demand (COD) determinations made by the "Rijksinstitut voor de zuivering van afvalwater" using an organic C/COD ratio of 0.324 . Organic $C$ concentrations in the waste water were multiplied by the amount of water discharged, measured by the "Rijkswaterstaat" (unpublished)

\begin{tabular}{|ccc|}
\hline Year & January-August & September-December \\
\hline 1972 & $9.2 \times 10^{6}$ & $17.0 \times 10^{6}$ \\
1973 & $10.8 \times 10^{6}$ & $21.5 \times 10^{6}$ \\
1974 & $10.7 \times 10^{6}$ & $25.6 \times 10^{6}$ \\
1975 & $12.3 \times 10^{6}$ & $17.5 \times 10^{6}$ \\
\hline
\end{tabular}

The daily import was highest in the time that the potato flour mills are active, from September to December (see Tab. 2). The average import for the years 1974-1975 was $33.0 \times 10^{6} \mathrm{~kg} \mathrm{C} \cdot$ year $^{-1}\left(350 \mathrm{~g} \cdot \mathrm{m}^{-2} \cdot\right.$ year $\left.^{-1}\right)$.

\section{Importof plantmaterialfrom thesalt marshes}

Primary production of higher plants occurs on the salt marshes $\left(9 \mathrm{~km}^{2}\right)$ along the south- and eastside of the Dollard. Plant remains are transported to the tidal flats with high floods in autumn and winter. It is not clear, however, which part of the production is carried to the tidal flats in this way, and to what extent it is counter- 
balanced by sedimentation in the marshes of suspended organic matter brought in by the floods. Some measurements were made in other estuaries, but it seems to depend strongly on the geography and hydrography of the area and on the type of vegetation, whether one or the other factor is more important. Teal (1962), Nixon \& Oviatt (1973) and Heinle \& Flemer (1976) have found that between 45 and less than $1 \%$ of the marsh production was transported to the adjacent estuaries.

Most of the marsh surface in the Dollard has a short vegetation; Puccinellia maritima, Festuca rubra and Agrostis stolonifera are dominant species on large parts of the marsh surface (Fresco, unpublished)*. These areas are grazed irregularly by cattle. About $10 \%$ of the area is covered with high growing vegetations: Scirpus maritimus, Spartina townsendii, Aster tripolium or Phragmites communis* with an estimated production rate of $2000-3000 \mathrm{~g}$ dry material $\mathrm{m}^{-2}$. year ${ }^{-1}$. If it is assumed that in the short vegetation area, export and sedimentation are in balance and from the high vegetation area $50 \%$ of the produced material with a carbon content of $45 \%$ (Keefe, 1972) is transported to the tidal flats, this amounts to $90 \times 10^{4} \times 0.50 \times 0.45$ $\times(2000-3000) \mathrm{g}=0.4-0.6 \times 10^{6} \mathrm{~kg} \mathrm{C} \cdot$ year $^{-1}$.

\section{Primaryproduction in the waterphase}

Some indicative measurements by Cadee \& Hegeman (1974) showed that the primary production in the waterphase is low, due to the high turbidity. From April 1972 to April 1973 they measured $13 \mathrm{~g} \mathrm{C} \cdot \mathrm{m}^{-2}$ year $^{-1}$ fixed in the tidal chanels. When extrapolating these data to the whole Dollard area, it must be taken into account that the water covers the tidal flats $\left(79 \mathrm{~km}^{2}\right)$ during about half of the tidal cycle, and covers only the tidal channels $\left(14 \mathrm{~km}^{2}\right)$ during the whole period. Taking this correction into account, the phytoplankton production in the Dollard was estimated to be $(0.5 \times 79 \times 13+14 \times 13) \times 10^{6} \mathrm{~g}=0.7 \times 10^{6} \mathrm{~kg} \mathrm{C} \cdot \operatorname{year}^{-1}\left(7.5 \mathrm{~g} \mathrm{C} \cdot \mathrm{m}^{-2} \cdot\right.$ year $\left.^{-1}\right)$.

\section{Primary production and mineralization on the tidal flats}

The primary production on the tidal flats is mainly due to diatoms, although blue-green algae seem to predominate in some parts. Gross carbon production was calculated from oxygen measurements by applying a conversion factor of 0.28 (Vollenweider, 1969). For the conversion of oxygen used during mineralization measurements to organic carbon respired, a higher value of 0.31 was used because not only diatoms are mineralized, but also allochthonus detritus with a higher carbohydrate content.

The primary production shows a peak in spring whereas the mineralization has a broad peak in summer. The average gross production rate from 16 measurements at different stations and spread over the whole year gave a value of $117 \mathrm{~g} \mathrm{C} \cdot \mathrm{m}^{-2}$.

* Unpublished information from the Lab. voor Plantenoecologie der R.U. 
year ${ }^{-1}$. Carbon consumption was calculated from data obtained at the same stations to be $196 \mathrm{~g} \mathrm{C} \cdot \mathrm{m}^{-2} \cdot$ year $^{-1}$. Extrapolation to the whole area of the tidal flats in the Dollard $\left(79 \mathrm{~km}^{2}\right)$ gives a total benthic gross production in 1975 of $9.3 \times 10^{6} \mathrm{~kg} \mathrm{C}$. In the calculation of the total benthic oxygen consumption, the bottom surface of the tidal channels $\left(14 \mathrm{~km}^{2}\right)$ is included in the total area, giving $18.2 \times 10^{6} \mathrm{~kg} \mathrm{C}$ in 1975 . If the consumption rate in the bottom of the tidal channels differs by a factor 2 from that measured on the tidal flats, the total benthic consumption in the Dollard would be $2.7 \times 10^{6} \mathrm{~kg}$ higher or $1.4 \times 10^{6} \mathrm{~kg}$ lower than is calculated here.

\section{Mineralization in the waterphase}

Mineralization in the waterphase was determined on 7 cruises in the main tidal channel at low tide and 2 surveys over the tidal flats at high tide (see table 1). Normal BOD values are between 0.1 and $2 \mathrm{mg} \mathrm{O} \cdot 1^{-1}$ day $^{-1}$ but in the polluted area in the south east of the Dollard values up to $50 \mathrm{mg} \cdot 1^{-1} \cdot \mathrm{day}^{-1}$ are measured. The amount of carbon mineralized in the water was calculated from the data in table 1 for the two water bodies: $365 \times 0.58 \times 0.31 \times 92.1 \times 10^{6} \mathrm{~g} \mathrm{C}+365 \times 7.6 \times 0.31 \times 1.35 \times$ $10^{6} \mathrm{~g} \mathrm{C}=7.2 \times 10^{6} \mathrm{~kg} \mathrm{C}$ year $^{-1}$.

\section{Burying of organic matterin the sediment}

A correction of the calculated import of organic carbon by sedimentation of suspended matter has to be made for the amount of carbon that is buried in the deeper layers of the sediment. When a new layer of one centimeter is deposited on the surface on the lower side one centimeter of sediment is excluded from the bioturbation layer. The latter was assumed to be buried and lost from the ecosystem. This loss is calculated as follows. The average organic carbon content of the surface sediment $(0-10 \mathrm{~cm})$ is $14.2 \mathrm{~g} \mathrm{C} \cdot \mathrm{kg}^{-1}$ (dry weight). There is no regular pattern of increase or decrease of the organic content with depth down to 50 or $60 \mathrm{~cm}$. Per year $0.7 \times 10^{9} \mathrm{~kg}$ suspended matter is imported and the same amount must be buried, with an organic carbon content of $14.2 \mathrm{~g} \cdot \mathrm{kg}^{-1}$. Thus $14.2 \times 0.70 \times 10^{6} \mathrm{~kg}=9.9 \times 10^{6} \mathrm{~kg} \mathrm{C} \cdot$ year $^{-1}$ is buried in the Dollard.

\section{Carbon ingested by higher levels}

The amount of carbon ingested by the highest trophic levels (large crustaceans, fishes and birds) is not included in the calculations because there are too many incertainties in the determination of their standing stocks at the moment. With respect to birds, a rough estimate can be made. Hulscher (pers. comm.) calculated from several countings the average numbers of birds feeding in the Dollard. Their food intake, when derived from laboratory measurements, can be approximated to be $0.26 \times 10^{6} \mathrm{~kg}$ C. year $^{-1}$. 
Table 3

Preliminary organic carbon budget for the Dollard constructed from the data calculated above

\begin{tabular}{|c|c|c|c|}
\hline \multicolumn{2}{|l|}{$\begin{array}{l}\text { Import/production } \\
\text { in } 10^{6} \mathrm{~kg} \mathrm{C} \mathrm{year}^{-1}\end{array}$} & \multicolumn{2}{|l|}{$\begin{array}{l}\text { Export } / \text { mineralization } \\
\text { in } 10^{6} \mathrm{~kg} \mathrm{C} \text { year }^{-1}\end{array}$} \\
\hline $\begin{array}{l}\text { from North sea }+ \\
\text { River Ems particulate max. } 3 \\
\text { from Westerwoldse A } \\
\text { from salt marshes } \\
\text { primary production water } \\
\text { primary production sediment }\end{array}$ & $\begin{array}{r}37.1 \\
33.0 \\
0.5 \\
0.7 \\
9.3\end{array}$ & $\begin{array}{l}\text { to North Sea dissolved } \\
\text { mineralization water phase } \\
\text { mineralization sediment } \\
\text { buried }\end{array}$ & $\begin{array}{r}? \\
7.2 \\
18.2 \\
9.9\end{array}$ \\
\hline $\max .8$ & 80.6 & & 35.3 \\
\hline
\end{tabular}

The total amounts of organic carbon entering and leaving the Dollard in a one year period are listed in Table 3.

\section{DISCUSSION}

Table 3 shows clearly the discrepancy between the two totals. This may be attributed in part to errors in measurements. In addition one or more of the following assumptions may be wrong: (1) Sedimentation of organic matter can be derived from sedimentation of total suspended matter. (2) Measurements on relatively small samples can be extrapolated to the whole surface or water volume of the Dollard. (3) Production and consumption values, measured as changes in oxygen concentration, are correctly converted to organic carbon by applying the conversion factors 0.28 and 0.31 , respectively. (4) The definition of the photic period for the benthic primary production is correct. (5) Tidal or diurnal changes in benthic oxygen consumption are of a small size.

The first assumption is the most uncertain one. It concerns one of the quantitatively most important items in the budget, and investigations to support this assumption remain necessary.

A third possibility is that some important factors influencing the carbon budget have been neglected. Perhaps the most important one is the export of dissolved organic matter to the outer part of the estuary. Indications for this can be derived by the gradients in dissolved organic phosphorus compounds (de Jonge \& Postma, 1974) and humic acids in the water.

From the data listed in Table 3 some more conclusions can be drawn, independent of the first assumption mentioned: (a) The waste discharges from the Westerwoldse A make up a considerable part of the total import. (b) Primary production occurs nearly exclusively on the tidal flat surface, whereas the production in the waterphase is negligibly small. (c) The mineralization in the sediment is quantitatively more important than that in the waterphase, although most of the organic matter is imported with the water. (d) The yearly in situ primary production is more than two times smaller than the mineralization of organic carbon in the same period. Thus the im- 
ported detritus should be the most important source of carbon for the foodwebs in the Dollard. Postma (1954) and de Jonge \& Postma (1974) came to the same conclusion for the whole Wadden Sea on basis of gradients in the concentration of different phosphorus compounds.

Although not included in the budget, the amount of carbon ingested by birds can be approximated to be less than $1 \%(0.26: 28.1)$ of the total amount of carbon mineralized.

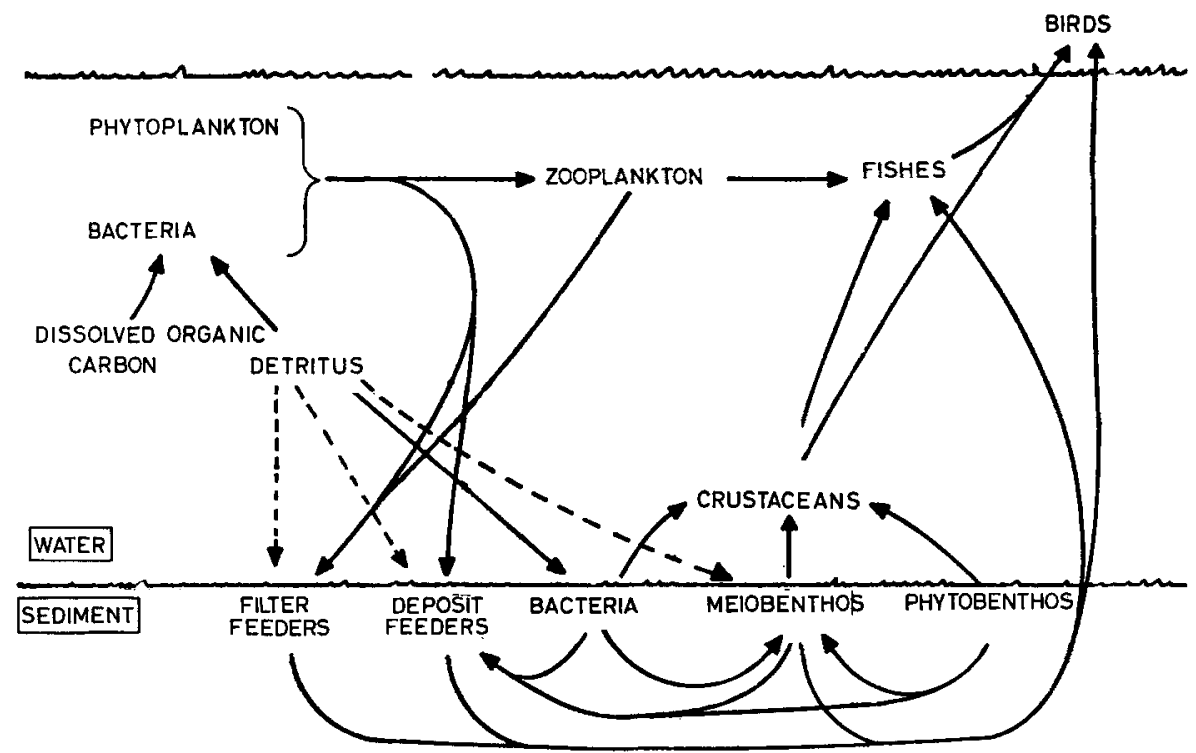

Fig. 2: Schematic diagram of suggested food relationships between the main groups or organisms in the estuary. The broken lines are supposed to be of minor importance

A few remarks can finally be made on the place of bacteria in the foodwebs in the Dollard. Publications of Newell (1965), Fenchel (1972) and others suggest that in marine benthic systems decomposition of detritus is mainly carried out by bacteria, and that deposit- and filter-feeders excrete the detritus taken up after digesting the bacteria, algae and protozoa attached to it. Literature on this subject is scarce, however, and restricted to only a few organisms. Mechanical breakdown of detritus particles by macrobenthic organisms favours the decomposition rate by bacteria (Hargrave, 1970).

Under natural conditions dissolved organic compounds are mineralized by bacteria. They keep the concentration of every single compound so low that higher organisms are not able to take them up fast enough for growth (Wright $\&$ Hobbie, 1966; Hollibaugh, 1976).

A schematic diagram of the main food relationships which are supposed to exist in the Dollard is given in Figure 2. The amount of carbon mineralized in the Dollard is considerable, and if bacteria are the main organisms involved in the first steps of 
the mineralization, the availability of food for higher organisms would depend not merely on primary production, but to a large extent also on bacterial production.

The basic biological processes in this intertidal ecosystem, including the waterphase, seem to be concentrated in a very thin layer of sediment. This layer is between a few millimeters and perhaps $2 \mathrm{~cm}$ thick, because diatoms and bacteria are most numerous in this part of the sediment.

Acknowledgements. Miss W. H. Knol carried out most of the practical work. Prof. $\mathrm{H}$. Veldkamp, Dr. P. de Wolf, Drs. H. G. J. Schröder and Drs. F. Colijn gave valuable advice for the investigation and the manuscript.

\section{LITERA'TURE CITED}

Cadee, G. C. \& Hegeman, J., 1974. Primary production of the benthic microflora living on tidal flats in the Dutch Wadden Sea. Neth. J. Sea Res. 8, 260-291.

Caspers, H., 1968. Der Einfluß der Elbe auf die Verunreinigung der Nordsee. Helgoländer wiss. Meeresunters. 17, 422-434.

Dorrestein, R., 1960. On the distribution of salinity and of some other properties of the water in the Ems-estuary. Verh. K. ned. geol. - mijnb. Genoot. (Geol.) 19, 279-292.

Fenchel, T., 1972. Aspects of decomposer food chains in marine benthos. Verh. dt. zool. Ges. 65, 14-22.

Groot, S. J. de \& Postma, H., 1968. The oxygen content of the Wadden Sea. Neth. J. Sea Res. $4,1-10$.

Hargrave, B. T., 1970. The effect of a deposit-feeding amphipod on the metabolism of benthic microflora. Limnol. Oceanogr. 15, 21-30.

Heinle, D. R. \& Flemer, D. A., 1976. Flows of materials between poorly flooded tidal marshes and an estuary. Mar. Biol. 35, 359-373.

Hollibaugh, J. T., 1976. The biological degradation of arginine and glutamic acid in sea water in relation to the growth of phytoplankton. Mar. Biol. 36, 303-312.

Jonge, V. N. de \& Postma, H., 1974. Phosphorus compounds in the Dutch Wadden Sea. Neth. J. Sea Res. 8, 139-153.

Keefe, C. W., 1972. Marsh production: A summary of the literature. Mar. Sci. 16, 163-181.

Kühl, H. \& Mann, H., 1954. Über die Hydrochemie der unteren Ems. Veröff. Inst. Meeresforsch. Bremerh. 3, 126-158.

- - 1973. Untersuchungen zur Hydrobiologie der unteren Ems. Arch. FischWiss. 23, 243-268.

Manuels, M. W. \& Postma, H., 1974. Measurements of ATP and organic carbon in suspended matter of the Dutch Wadden Sea. Neth. J. Sea Res. 8, 292-311.

Mebius, L. J., Dekker, A. \& ten Have, J., 1957. The "Kurmies" method, a rapid and reliable titrimetric method for the determination of the total organic matter content of the soil. Chem. Weekbl. 53, 291-294.

Ministerie van Verkeer en Waterstaat, 1974. Getijdetafels voor Nederland. Staatsuitgeverij, Den Haag, 1975.

Newell, R., 1965. The role of detritus in the nutrition of two marine deposit feeders, the prosobranch Hydrobia ulvae and the bivalve Macoma balthica. Proc. zool. Soc. Lond. 144, 24-45.

Nixon, S. W. \& Oviatt, C. A., 1973. Ecology of a New England salt marsh. Ecol. Monogr. 43, $463-498$.

Pomeroy, L. R., 1959. Algal productivity in salt marshes of Georgia. Limnol. Oceanogr. 4, 386-397.

Postma, H., 1954. Hydrography of the Dutch Wadden Sea. Archnéerl. Zool. 10, 405-511.

- 1961. Transport and accumulation of suspended matter in the Dutch Wadden Sea. Neth. J. Sea Res. 1, 148-190. 
Reenders, R. \& Meulen, D. H. van der, 1972. De ontwikkeling van de Dollard over de periode 1952-1969/1970. Studiedienst Rijkswaterstaat, Delfzijl, Nota 72-1 (in Dutch).

Straaten, L. M. J. U. van, 1960. Transport and composition of sediments. Verh. K. ned. geol.mijnb. Genoot. (Geol.) 19, 279-292.

Teal, J. M., 1962. Energy flow in the salt marsh ecosystem of Georgia. Ecology 43, 614-624.

Vollenweider, R. A. (Ed.), 1969. A manual on methods for measuring primary production in the aquatic environment. Blackwell, Oxford, $225 \mathrm{pp}$.

Wright, R. T. \& Hobbie, J. E., 1966. Use of glucose and acetate by bacteria and algae in aquatic ecosystems. Ecology 47, 447-464.

Author's address: F. B. van Es

Department of Microbiology

Kerklaan 30, Haren (Gn)

The Netherlands 